\author{
International Court of Justice
}

\title{
SOVEREIGN IMMUNITY AND THE ICJ'S RULING IN FERRINI
}

\author{
Marcin Menkes*
}

\section{Introduction}

On 23.12.2008 the Federal Republic of Germany, acting upon Article 1 of the European Convention for the Peaceful Settlement of Disputes 1957, instituted proceedings before the International Court of Justice against the Italian Republic. Germany alleged that an Italian judgment in the Ferrini case of $11.3 .2004^{1}$, confirmed in subsequent judgments of 29.5.2008 ${ }^{2}$ and $21.10 .2008^{3}$, together with the exercise of enforcement measures against the German Villa Vigoni - used for non-commercial purposes - captured the quintessence of the Italian rulings which violated Germany's immunity from jurisdiction and execution under international law. The Hellenic Republic intervened in the case.

* Warsaw School of Economics.

1 Corte di Cassazione, sezioni unite, N. 5044/04, sentenza 11.3.2004, Diritto e Giustizia 16.03.04.

2 Decision on enforecibility of a Greek judgment in Prefecture of Voiotia, Cassazione, sezioni unite, sentenza 29.5.2008, no 14199, http://bit.ly/rfmVzO (6.02.2012).

3 Sentence concerning Germany's liability for damages stemming from killing of 203 persons in Civitella, Cornia and San Pancrazio in Arezzoregion on 29.6.1944.Information concerning the rulling, Stragi naziste: la Cassazione condanna la Germania a risarcire le vittime, 'Corriere Della Sera', 21.10.2008, http://bit.ly/yuhzgu (6.02.2012). 
Basing on the Italian precedent established by the Corte di Cassazione by the time at which the proceedings were instituted before the ICJ, about 250 damages claims against Germany were filed in Italian courts, each of which related to facts that occurred following Italian surrender to the Allies and the declaration of war against Germany in $1943^{4}$. Those claims addressed several types of incidents: 1) the detention of Italian citizens on Italian soil and their subsequent deportation to Germany and German-occupied territories for forced labour; 2) the denial of POW status to captured members of the Italian armed forces and their deportation to Germany and German-occupied territories for forced labour; 3) the perpetration of war crimes against the Italian civilian population in order to repress resistance. Furthermore, Greek citizens filed enforcement petitions in Italy on the basis of Greek judgments rendered in similar cases. In response, Germany claimed sovereign immunity. Given the high amounts of damages awarded (see below) and the need to establishing special judicial services for the purposes of monitoring such claims, not to mention the existence of legal counsel in hundreds of proceedings, the German authorities issued a diplomatic protest alleging a violation of their immunity privilege under international law ${ }^{5}$.

The alleged violations did not undermine an understanding between Germany and Italy as to the legal qualification of German armed forces' conduct during WWII as war crimes and the mutual condemnation thereof. Both governments considered, however, that the acts in question constituted acta de iure imperii, in respect of which States enjoy jurisdictional immunity. Despite the Italian government's legal position, these bilateral declarations had no impact on the independence of the Italian judiciary, which had a divergent view of the matter.

On 3.2.2012, by 12 votes against 3 in respect of jurisdictional immunity and by 14 votes to 1 in respect of immunity from the

4 Requête introductive d'instance, enregistrée au Greffe de la Cour le 23.12.2008, Immunités juridictionnelles de l'Etat, (Allemagne c. Italie), at paras 7, 10, 12. For description of certain damages claims see: Memorial of the Federal Republic of Germany, 12.6.2009, at paras 23-45.

5 For instance Dichiarazionecongiunta,adottatanell'occasionedeiconsultazioni intergovernativeitalotedesche, Trieste 18.11.2008, http://bit.ly/xpmaqu(English and French translations attached to German motion to institute proceedings before the ICJ). 
enforcement of Greek judgments, the ICJ held that Germany's rights had been violated ${ }^{6}$.

\section{Damages for Victims of Persecution}

On the basis of article 77(4) of the Peace Treaty with Italy of $1947^{7}$, and without prejudice to other decisions of the Allied Powers, Italy waived on its behalf and on behalf of its nationals all claims against Germany and German nationals acquired between 1.9.1939 and 8.5.1945.

The principles of compensation for victims of the III Reich, including Italian citizens, were established in the Federal Compensation Law of 1953 (BEG, Bundesentschädigungsgesetz). According to the BEG, only those victims of "national socialist persecution" who were domiciled or permanent resident in Germany on 31.12.1952 were entitled to compensation $^{8}$. Despite weakening of the criteria for indemnification (in 1956 and 1965), victims were nevertheless required to prove that on 1.10.1953 they were entitled to refugee status ${ }^{9}$. Accordingly, a large group remained unable to establish any right to compensation.

Given the existence of a tremendous number of damages claims from all over the world filed in its domestic courts, Germany decided in some instances to pay compensation by way of a lump sum to be subsequently redistributed by the concerned government institutions ${ }^{10}$. This was the case in respect of Italy. The issue of distribution was addressed in two Agreements dated 2.6.1961. In exchange for 40mln Deutschemarks, Italy declared that all outstanding claims had been settled, pursuant to both Agreements, against German natural or legal persons, as regards any

${ }^{6}$ ICJ, Jurisdictional Immunities of the State (Germany v. Italy: Greece intervening), 3.2.2012.

7 Available at http://bit.ly/y0q2tr (6.02.2012).

8 Alternatively a person had to meet the statutory definition of a "repatriate", "expellee", "refugee" or "stateless person". For a broad analysis of German compensation schemes see: Re Holocaust Victim Assets Litigation, U.S. District Court (N.Y.), Special Master's Proposal, 11.9.2000, http://1.usa.gov/y55pAS (10.05.2012).

9 Supra note 6, at paras 20-26.

10 Supra note 8. 
rights or circumstances which arose during the period between 1.9.1939 to 8.5.1945. The Italian government also indemnified Germany against any possible judicial proceedings or other legal action initiated by Italian natural or legal persons as regards such claims. Damages were granted to

"Italian nationals who, on grounds of their race, faith or ideology were subjected to National-Socialist measures of persecution and who, as a result of those persecution measures, suffered loss of liberty or damage to their health, and for the benefit of the dependents of those who died in consequence of such measures".

Compensation was distributed among victims, including Italian citizens, by the "Remembrance, Responsibility and Future Foundation" and a chain of "partner organisations". Upon its establishment (on 2.10.2000), thousands of persons formerly detained and deported for forced labour applied for damages to which they had not been previously entitled. In the following year the German authorities declared, however, that the III Reich was legally incapable of depriving POWs of such status by way of a unilateral decision. Accordingly, they de iure remained prisoners of war and the use of their labour did not amount to a breach of international law. Entitlement to damages was restricted to three categories of persons: those deported to concentration camps, agriculture forced workers and forced workers ${ }^{11}$. The latter category was, however, limited to those whose persecution involved working in one of the named German labour camps contained in a list, albeit that this list contained merely several hundred of over 20,000 such camps. Consequently, of over 130,000 Italian damages claims a mere 3 thousand were upheld. For instance, some 90,000 claims by the so-called Internai Militari Italiani - Italienische Militär-Internierten were rejected ${ }^{12}$. Furthermore Germany labelled some, albeit relatively few, such payments as "humanitarian aid" as opposed to damages for forced labour.

11 Rai Storia, Destinazione inferno. Gli schiavi di Hitler, http://bit.ly/xSWxHf (21.02.2012); Rai Storia, Prigionieri - L'ultimo inverno, 21.02.2012.

12 A complaint of former Italian military personel to the ECHR has been declared inadmissible, Associazione Nazionale Reduci and 275 others v. Germany, application no. 45563/04, 4.10.2007. 


\section{Examination Proceedings Before Domestic Courts}

On 23.9.1998 Luigi Ferrini filed a claim against Germany for pecuniary and non-pecuniary damages suffered as a result of his detention in August 1944 by German armed forces and his subsequent deportation to forced labour in a German munitions factory ${ }^{13}$. At the time of the arrest he had barely turned 18 years old and had not participated in any military operations ${ }^{14}$. Ruling in the first instance on 3.11.2000, the Tribunale di Arezzo held that the conduct to which the claim pertained was an exercise of sovereign powers and, as such, was covered by the defendant's immunity. The Corte di Appello di Firenze upheld this judgment, following which the plaintiff filed a cassation.

The Corte di Cassazione first recalled its earlier ruling in Italian Transport Workers' Federation ${ }^{15}$ in which it observed that, according to the par in parem non habet iurisdictionem principle, States enjoy jurisdictional

13 According to IHL customary norms civilian population cannot, as a matter of principle cannot, be forced to uncompensated or abusive forced labour; courts consider forcing prisoners to engage in work related the armed conflict as a war crime (J.-M. Henckaerts, L. Doswald-Becks, Customary International Humanitarian Law Volume I: Rules, Cambridge 2009, at pp. 330-334). See also articles 40, 95 of IV Geneva Convention 1949. As for principles on employing POW to work see for instance III Geneva Convention of 1949, articles 49-50. See also Article 6(b) of the Charter of the International Military Tribunal.

14 G. Masiero, Internato in un lager tedesco: la Germania deve risarcirlo, http://bit.ly/ zQp2xJ; R. Monteforte, Ex deportati, la svolta arriva dalla Cassazione storica sentenza: «Chi ha vissuto il lager può chiedere il risarcimento alla Repubblica federale tedesca», http://bit.ly/ zYB57i (21.02.2012).

15 Members of the Federation filed a damages claim against the U.S.A. for the harm suffered due to routine low-altitude training flights by the U.S. air forces stationed in the Trento province. According to the plaintiff flight above inhabited zones and road junctions, which caused numerous accidents, occasionally lethal, thus violated the Universal Declaration of Human Rights and the 1966 International Covenant on Civil and Political Rights. The plaintiff argued that in view of gravity of the breaches, on the hand, the court was obliged to accepts jurisdiction in the matter while, on the other, the individual right to effective protection of human rights, including preventive actions, shall be recognized. Accordingly it request a ban of flights. Both the Italian Prime Minister and Minister of Defence, who intervened in the case, argued that the court did 
immunity in civil proceedings as a matter of customary international law. Pursuant to the doctrine of restrictive immunity, a domestic court is bound to declare that it has no jurisdiction in cases concerning a foreign State whose conduct amounted to an "immediate and direct objectivisation of its powers iure imperii" (le attività degli Stati esteri che costituisca estrinsecazione immediata e diretta del loro jure imperii). In that earlier case, the Court of Cassation found that a national defence training exercised within a military alliance undoubtedly fell within the scope of sovereign powers ${ }^{16}$. Accordingly, limitations on the exercise of human rights alleged to have occurred as a result of the conduct in question ${ }^{17}$ constituted neither an obstacle to imputing the act to the defendant State, nor an obstacle to qualifying the act in question as an exercise of State competences. The allegedly hazardous nature of conduct falling within the scope of sovereign powers does not alter its legal nature since the legal test of acta de iure imperii is objective in nature. In Ferrini the Italian court was thus entirely convinced that the relevant military operations pertained to Germany's sovereign powers.

Nevertheless, the judges in that case queried whether a state enjoys jurisdictional immunity in respect of acts, which, unlike the aforementioned, were marked by particular brutality and amounted to international crimes. Since such acts threaten universal values, they cannot be considered as constituting the interests of a particular State.

Applying those considerations to the Ferrini case, the Corte di Cassazione held that, as a matter of principle, courts may not exercise jurisdiction over proceedings concerning State acts undertaken during an armed conflict. The judges found, however, that the absence of legal means to stay military operations or coerce change in conduct by opposing an

not have jurisdiction, Corte di Cassazione, sezioni unite, 3.8.2000, n. 530. A summary of the judgment AT http://bit.ly/pKEj4g (12.10.2011).

16 Similarly previous judgements: Cassazione, sezioni unite, 2.31964 n. 1467, 13.5.1963, n. 1178, 17.10.1955, n. 3223.

17 The ECHR held on numerous occassions that enjoyment by a foreign state of the immunity protection in judicial proceedings does not per se violate European Convention for the Protection of Human Rights and Fundamental Freedoms. See for instance three judgements of November 21.: McElhinney v. Ireland (application no. 31253/96), Al-Adsani v. United Kingdom (application no. 35763/97), Fogarty v. United Kingdom (application no. 37112/97). 
individual legal interest does not free the perpetrator of an illicit act from civil or criminal responsibility. Furthermore, according to article 10 of the Italian Constitution ${ }^{18}$, international norms protecting human freedom and dignity, as fundamental values, and the criminalisation of acts threatening those core values, automatically became a part of the domestic legal order and as such can be applied as criteria to assess the legalityof the act.

The court also recalled a Greek Supreme Court judgment (Areios Pagos), equally contested by Germany, which held that a foreign State perpetrator of grave breaches of HRs against the Greek population on Greek soil did not enjoy immunity from jurisdiction in those proceedings. Whilst the Italian court rejected the reasoning of that court, it concurred with the ultimate conclusions in the Areios Pagos ${ }^{19}$ case. The Corte di Cassazione reiterated that international crimes, threatening humanity and international community, are incapable of justification and are - in some cases - subject to universal jurisdiction. The pursuit of the perpetrators of such acts may constitute an international law duty. Accordingly, universal jurisdiction must also apply in respect of civil proceedings concerning such acts. The prohibition of certain acts is matched by an international law duty to not recognise the unlawful situation and to curtail such unlawfulness. Enabling a State that had acknowledged its own responsibility for the conduct to benefit from immunity would undermine the foundations of the international community. In the case of a conflict between norms, account should be taken of the hierarchical precedence

18 According to Article 10(1) of the Constitution, Italian legal order "conforms to the generally recognized principles of international law".

19 Prefecture of Voiotia v. Federal Republic of Germany, no. 11, Judgment of 4.5.2000. The Greek court recalled article 11 of the European Convention on State Immunity of 1972 (henceforth: the European Convention), which stipulates that a state cannot invoke immunity claim immunity from the jurisdiction of a court of another Contracting State in proceedings which relate to redress for injury to the person or damage to tangible property, if the facts which occasioned the injury or damage occurred in the territory of the State of the forum, and if the author of the injury or damage was present in that territory at the time when those facts occurred. This customary rule (thus binding countries non-parties to the Convention, such as Greece) allegedly applies also to acta de iure imperii. Although the Italian court pointed out that article 31 of the Convention excludes conduct of armed forces on the territory of another Contracting State from the scope of regulation, it held that commission of an international law crime deprives a state-perpetrator of possibility to enjoy international law privileges. 
of certain norms (the Corte di Cassazione recalled the dissenting opinion of eight justices in Al-Adsani), allowing individual recourse by victims in civil proceedings (in accordance with the Furundzija judgment ${ }^{20}$ ).

Although the Italian court acknowledged that this exception from jurisdictional immunity has not been yet broadly accepted, it considered that the evolution of HRs inevitably results in diminishing of the conservative norm of State immunity, which itself dates back to the classical international law era. It stressed that in similar cases, where various domestic courts had accepted the validity of State immunity, the acts in question were not committed in the State wherein the proceedings were underway.

\section{Proceedings Before the ICJ}

Article 27 of the European Convention for the Peaceful Settlement of Disputes, on which basis Germany instituted proceedings, states that the Convention applies to the settlement of legal disputes stemming from facts that arose upon the entry into force of the Convention on 18.4.1961. Italy did not contest the ICJ's competence ratione materiae or ratione temporis, since both parties agreed that the case concerned the Italian judgments in 2004-2011 and not per se the facts of WWII. Nevertheless Italy argued that, given its failure to meet its obligations towards victims of the grave breaches of IHL, Germany had forfeited the right to claim immunity in the proceedings at hand. Despite dismissal of the Italian counterclaim by the Court, Italy maintained that the case should be scrutinised against its historical background.

\subsection{Intertemporal Issues}

While the parties agreed on the customary nature of jurisdictional immunity, they differed as regards their assessment of the applicable law. Germany argued that the scope and purpose of such immunity should be assessed in accordance with laws in force at the time when the facts considered by the Italian courts actually occurred, whereas Italy

20 International Criminal Court for the Former Yugoslavia, case no. IT-95-17/1. 
considered that the law to be applied is that which was in force at the time the proceedings were instituted. The ICJ recalled article 13 of the ILC Articles on State Responsibility for Internationally Wrongful Acts, which stipulates that the legality of acts shall be assessed in accordance with the legal duties binding the State at the time they occur ${ }^{21}$. However, distinguishing between the German and Italian acts, the Court noted that the former took place between 1943 and 1945, whereas the latter - upon which the claim is based - over half a century later. The ICJ also noted that jurisdictional immunity is a procedural norm and hence subject to intertemporal principles other than those applicable to substantive provisions ${ }^{22}$. Accordingly, the law governing jurisdiction must be distinguished from the substantive norm applicable to the case at hand.

\subsection{Scope of the Sovereign Power}

Both parties agreed as to the nature and consequences of the distinction between acts de iure imperii and de iure gestionis; Italy acknowledged the iure imperii nature of the German conduct in question. This initial classification is crucial for the purposes of claiming jurisdictional immunity before a foreign court ${ }^{23}$, since the legality of any given act could be assessed in the light of relevant laws, subsequently applicable to acts of state or others (including acts undertaken in a purely private capacity or as part of commercial conduct). Such an assessment already constitutes an exercise of judicial powers, even in cases such as the Ferrini proceedings where the State claiming immunity had already recognized the unlawful nature of the conduct in question. There are, however, certain exceptions from this general principle, including the tort exception.

\subsection{Redress for personal injury and property damage}

According to Article 12 of the UN Draft Articles on Jurisdictional Immunities of States and Their Property (henceforth: the UN Convention),

21 Supra note 6, at para 58.

22 See: Arrest Warrant (Democratic Republic of Congo v. Belgium), I.C.J. Reports 2002, at para 60.

23 Supra note 6 , at para 60 . 
Article 11 of the European Convention and nine out of ten domestic laws on sovereign immunities cited by Italy, immunity from jurisdiction cannot be claimed in damages proceedings if the facts which occasioned the injury or damage occurred in the territory of the State of the forum, regardless as to whether such acts are categorised as iure imperii or iure gestionis. Italy argued that the limitation stemming from Article $31^{24}$ of the European Convention primarily applies to a conflict of laws regulating the stationing of foreign armed forces with the consent of the territorial sovereign ${ }^{25}$.

Although none of the legal acts quoted distinguishes among acts de iure imperii and de iure gestionis, the ICJ noted that there have been judicial exceptions in this respect, while the discussed provision of the UN Convention has given rise to criticism ${ }^{26}$. Bound by the limits of the application, the ICJ found that its role was not to rule on legality of the acts, perpetrated mainly by German armed forces during II WW in Italy, but to scrutinise the applicability of the customary tort exception from jurisdictional immunities to acts de iure imperii. The Court rejected Italy's restrictive interpretation of Article 31 of the European Convention as being contrary to the literal meaning thereof and the ILC's commentary. It agreed, however, that the exemption of military operations from the scope of the Convention's tort exception merely means that international customary law would need to be applied in the case at hand. The Court identified a number of domestic rulings recognising jurisdictional immunities even in respect of international crimes $^{27}$, and pointed to domestic laws which specifically recognise such an exception or upon which basis national courts have found such an exception to exist. The ICJ also stressed that two States, having already ratified the UN Convention, issued interpretative declarations which make clear that the Convention does not apply to military operations. Accordingly, it

24 The European Convention, Article 31: Nothing in this Convention shall affect any immunities or privileges enjoyed by a Contracting State in respect of anything done or omitted to be done by, or in relation to, its armed forces when on the territory of another Contracting State.

25 Supra note 6, at para 62.

26 Ibidem, at para 64.

27 For instance: Polish Supreme Court, IV CSK 465/2009, Decision of 29.10.2010 Biuletyn Sądu Najwyższego 2010/11. See: Ibidem, at para 68. 
held that States enjoy jurisdictional immunity in respect of their armed forces, whose operations constitute an exercise of sovereign powers, even insofar as including unlawful acts which occurred abroad during an armed conflict ${ }^{28}$.

\subsection{Gravity of the conduct}

Italy also argued that the acts considered by the domestic courts amounted to violations of IHL and ius cogens norms. Here the ICJ perceived an inconsistency in alleging that the loss of jurisdictional immunity, which is a procedural defence, is due to the gravity of the conduct, which touches upon the substance of the conduct ${ }^{29}$. The Court found no legal authority for such an exception in the UN Convention, the European Convention, domestic rulings (apart from the aforementioned Italian and Greek judgments), national practice or domestic codifications (apart from the 1996 exception adopted in the U.S. in respects of States supporting international terrorism ${ }^{30}$ ). Referring to the ECHR and the Al-Adsani ${ }^{31}$ and Kalogeropoulou ${ }^{32}$ cases, the ICJ rejected, at the current stage of development of international law, that jurisdictional immunity was related to the gravity of the IHL or HRs violation ${ }^{33}$. As for the primacy of ius cogens norms, the ICJ declared that no conflict exists between those norms (or the compensatory duty), and that a procedural duty exists to recognise foreign State immunity, since application of procedural norms renders the conduct in question lawful ${ }^{34}$. The possible

28 Ibidem, at paras 77-78.

29 Ibidem, at para 82.

3028 USC 1605A, Terrorism Exception to the Jurisdictional Immunity of a Foreign State, http://bit.ly/yfb0CW (8.02.2012).

31 One shall not forget, however, that the case was decided by nine votes against eight.

32 Kalogeropoulou and others v. Greece and Germany, December 12.12.2002, ECHR Reports 2002-X, at p. 417.

33 At the same time the ICJ stated that the case concerned responsibility of a state and not its officers, which allowed to reject Italian arguments recalling reasoning of English judges in the Pinochet case, Supra note 6, at para 91.

34 Ibidem, at para 93-94, 97; see also: Armed Activities on the Territory of the Congo (New Application: 2002), at para 64 i 125 and Arrest Warrant (Democratic Republic of Congo v. Belgium), at paras 58 and 78. 
absence of alternative modes for victims to claim compensation did not alter this assessment ${ }^{35}$.

\subsection{ICJ's Conclusions}

Recognising Germany's right to immunity from jurisdiction and execution $^{36}$, the Court found Italy to be in breach of its international law duties. Simultaneously, the ICJ argued that a procedural impediment which prevents domestic courts from adjudicating on Germany's liability for damages is not equivalent to the absence of Germany's substantive law liability towards the Italian State or its citizens.

According to judge Bennouna, the latter issue was insufficiently scrutinised by the Court ${ }^{37}$. It does not suffice to state that a procedural obstacle is not equivalent to the absence of an unlawful act, where the illegality of such act is beyond doubt (given Germany's unequivocally condemnation thereof). He recalled that the purpose of immunity is to adequately allocate and exercise jurisdiction in accordance with international $\operatorname{law}^{38}$. Although a claim of immunity halts foreign judicial proceedings, by doing so the State accepts its responsibility for all alleged violations of $\operatorname{law}^{39}$. Any immunity claim is therefore tied to

35 The Court restricted deliberation on the impact denying compensation to the victims to a remark that it takes German decision with "surprise and regret", Supra note 6 , at paras 99, 101.

36 Court reasoning in terms of Germany's immunity from execution was very similar, especially given its broader scope than the protection of jurisdictional immunity.

37 Separate Opinion of Judge Bennouna.

38 Similarly: "Immunities are conferred to ensure an orderly allocation and exercise of jurisdiction in accordance with international law in proceedings concerning States, to respect the sovereign equality of States and to permit the effective performance of the functions of persons who act on behalf of States", Annuaire de l'Institut de droit international, Vol. 73, Naples Session (Italy), 2009.

39 "The State which seeks to claim immunity for one of its State organs is expected to notify the authorities of the other State concerned. This would allow the court of the forum State to ensure that it does not fail to respect any entitlement to immunity and might thereby engage the responsibility of that State. Further, the State notifying a foreign court that judicial process should not proceed, for reasons of immunity, against its State organs, is assuming responsibility for any internationally wrongful act in issue committed by such organs", Case Concerning Certain Questions of Mutual Assistance in Criminal Matters (Djibouti v. France), ICJ Judgment of 4.6.2008, I.C.J. Reports 2008, at para 196. 
a duty to adequately fulfil obligations stemming from international law responsibility ${ }^{40}$. Exceptionally, where the failure to fulfil those duties is manifested by barring access to one's own domestic courts, the State should not be able to claim immunity before a foreign court. It is precisely this element of exceptionality that prevents the opening of a "Pandora's Box of individual claims for reparation by all victims of armed conflicts". That was not the case here ${ }^{41}$. Although, as regards the compensatory efforts undertaken by Germany, judge Bennouna concurred with the majority opinion, he stressed that the Court's judgment should not be allowed to undermine international law provisions on international responsibility for unlawful acts. Bennouna referred critically to the Court's "mechanical" conception of the judicial task and its formalistic approach, which failed to take due account of the entire international law taxonomy (which in itself was described as contrary to the ICJ's functions).

Although the above reasoning justified the inadmissibility of private claims before Italian courts thus far, it remains unclear at which point Germany's refusal to compensate certain groups of victims will meet the requirement of exceptionality, thereby relieving domestic courts from the obligation to recognize Germany's jurisdictional immunity or whether, once this occurs, it would preclude another German application to the ICJ.

In his separate opinion, judge Keith is somewhat startling. Immediately following his analysis of the historical differentiation between de iure imperii and de iure gestionis, he focused on the tort exception from jurisdictional immunity which ignores the fact that, for the purposes of this exception, jurisdiction is based on territorial link (which was mentioned by the Court itself) ${ }^{42}$. The importance of the evolutionary nature of immunity was thus marginalised and the concept underpinning

40 Separate Opinion of Judge Bennouna, at paras 15, 21.

41 Separate Opinion of Judge Bennouna at para 24. To the contrary the Court stated, however, that it "...is not unaware that the immunity from jurisdiction of Germany in accordance with international law may preclude judicial redress for the Italian nationals concerned"; Supra note 6, at para 104.

42 Similarly judge Koroma from the tort exception, which according to the ILC's commentary mostly applies to transport accidents, goes to the signalled by the Commission exclusion of military operation from the scope of Conventional regulation, without mentioning that the said exception encompasses also exercise of sovereign powers, Separate Opinion of Judge Koroma, at para 6. 
it was perverted. Analysing the relationship between military operations and jurisdictional immunities, judge Keith drew an analogy with a gradual limitation of the absolute immunity towards immunity restricted to acta de iure imperii ${ }^{3}$. This is all the more surprising given the judge's declared support for the Court's argumentation, which after all agreed with the Italian position that exclusion of military operations from the scope of Conventional regulation means that and that only.

\section{Dissenting opinion - Giorgio Gaja}

Judge ad hoc Gaja mainly focused on the tort exception, in respect of which the Court concluded that it was inapplicable to military operations ${ }^{44}$. Although only eight parties to the European Convention and a further nine States have recognised the exception in their domestic law, internal legislation adopted over the last thirty years was only capable of offering a discretionary broadening of the immunity provided to third States. On the contrary, such legislation could not limit foreign privileges without risking international responsibility. In adopting substantive law provisions in this area, States must have acted in the belief that their conduct conforms to international law. At least some of those codifications were broadly known and none gave rise to objections by third States. Furthermore, none of those laws, nor the ILC's commentary to the UN Convention (which contains identical provisions) limit the tort exception from sovereign immunities to acts de iure gestionis. As for the McElhinney ruling, judge Gaja noted that the ECHR stated merely that a grant of immunity to a foreign state did not violate a victim's right to due process, and not that Ireland was legally obliged to recognise the United Kingdom's immunity.

43 Separate Opinion of Judge Keith: "The International Law Commission commentary states flatly that its draft Article 12 does not 'apply to situations involving armed conflicts' (para 16) (...) Also supporting that exclusion is the analogy provided by national law which in many countries at first recognized the absolute immunity of States from proceedings in their own courts, and later limited it (para 17)". Eventually judge states, however that, "while parallelism with private acts is not to be pressed beyond its limits, it is of interest".

44 Dissenting Opinion of Judge Ad Hoc Gaja. 
He argued that an analysis of legislative and judicial practice concerning military operations does not enable the identification of the commonly accepted scope of the tort exception. Differentiation in this field is unjustified both on grounds of the principle of equal attribution of responsibility to all State organs and in view of the rationale underpinning the broadening of sovereign immunity, which applies only to the stationing of foreign organs, including armed forces, with the consent of the territorial sovereign. In the absence of such permission from the territorial sovereign, there is no reason to grant primacy to the foreign state's sovereignty over that of the state in which the proceedings are underway, this being the place where the unlawful act(s) occurred. In such case at least, ius cogens violations should be excluded from the scope of sovereign immunity ${ }^{45}$.

On the one hand, the legal nature of the violated norm, which constitutes grounds for judicial proceedings, does not per se justify the denial of immunity to a foreign state. On the other hand, it cannot be accepted that the gravity of the act is decisive for the enjoyment of immunity protection, since this would mean that States were unable to claim immunity only in the case of ordinary torts.

\section{Dissenting opinion - Abdulqawi Yusuf}

Judge Yusuf found it deplorable that, although Italy had indicated the circumstances which allegedly deprived Germany of the right to claim immunity (failure to fulfil compensatory duties), these circumstances were largely ignored by the Court ${ }^{46}$.

The question before the Court did not concern abstract relations between HRs and immunities but, rather, particular crimes committed in Italy during WWII. He identified norms that oblige States to

45 See also Gaja's remarks concerning Hafner's initative at the ILC's working group to codify an exception "in the case of death or personal injury resulting from acts of a State in violation of human rights norms having the character of jus cogens" (Fiftyfourth session, Sixth Committee, Convention on jurisdictional immunities of States and their property, Report of the Chairman of the Working Group, UN Doc. A/C.6/54/L.12).

46 Dissenting Opinion of Judge Yusuf. 
compensate for unlawful conduct during armed conflict, in respect of which they bear responsibility. Even though individuals cannot rely upon such norms directly to claim damages, they are intended to be the ultimate beneficiaries of such compensation. According to Yusuf, the ICJ insufficiently scrutinised the legal consequences that arise when a State which has acknowledged its own responsibility denies compensation to victims by claiming immunity.

Judge Yusuf also noted that, while the historical justification for establishing immunities was the willingness to protect friendly relations between States, the protection of individual rights constitutes the driving power behind limiting the scope of the immunity doctrine. It would be trivial to conclude that the ICJ's judgment places States that have committed international crimes in a better position than those responsible for transport accidents and dishonest employers. Yusuf notes a more subtle implication: since the limitation of jurisdictional immunities is a process marked by domestic rulings, the ICJ's finding that some such rulings establish customary norms while others don't, may create the impression of "cherry-picking". The incoherence of domestic rulings reveals a lack of opinio iuris in the subject matter, so basing the judgment on quantitative criteria (from a very small sample) does not help to clarify the law.

According to Yusuf, given the development of HRs, a formalistic approach to immunities, which violates the principle of due process and the standard of adequate and effective compensation, may be considered disproportionate to the purpose and hence an abuse of the privilege ${ }^{47}$. At this point, however, it seems that judge Yusuf (similarly to Trindade) paid insufficient attention to the disjunction of two legal relationships: international responsibility and the duty of compensation.

He concluded that, if the above reasoning would be insufficient to grant legal protection to the victims of Nazi prosecutions, a gradual limitation of immunities should be based on judicial precedents. Certain legal areas thus remain in the "regulatory grey zone" until they are clarified by a court, which the Italian courts did. The problem with this argument is that, even if one considers the Italian judgments to constitute a contribution to the development of international (sic!) law,

47 Dissenting Opinion of Judge Yusuf, at paras 28, 30. 
then Germany's lack of consent should likewise be considered akin to the status of persistent objector.

\section{Dissenting opinion - Cançado Trindade}

Most critical in respect of the Court's judgment was judge Trindade, whose 88 page dissenting opinion (which exceeds the ICJ's 53 page judgment) rejects the Court's methodology, approach, reasoning and conclusions ${ }^{48}$.

Judge Trindade considered it illogical that Germany should seek to claim immunity on the basis of contemporary international law, whilst simultaneously seeking to apply laws in force during WWII so as to justify the lawful nature of the conduct in question. In his opinion, this amounted to a selective use of intertemporal law, contrary to the recta ratio of international law. It is difficult to support this opinion, given the distinction between substantial and procedural norms, which was the only reason provided by ICJ to support its conclusion that no conflict existed between jurisdictional immunity and the right to compensation.

Even though a majority of the judge's deliberations shed no new light, one shall agree that the Court's attempt to introduce rigorous time restraints from 2004 onwards, whilst the bulk of arguments presented by both parties and the Court's reasoning concerned earlier events, reveals the extent to which the application of immunity without any consideration of the facts or law governing the case was artificial.

Trindade explicitly stated that a distinction between immunity in civil and penal proceedings, stemming from the same facts, is contrary to contemporary legal standards ${ }^{49}$.

Judge Trindade's opinion is a particularly interesting supplement to the judgment. On each occasion where the ICJ felt itself not competent to adjudicate, judge Trindade expressed categorical conclusions ${ }^{50}$, ruling

48 Dissenting Opinion of Judge Cançado Trindade.

49 Dissenting Opinion of Judge Cançado Trindade, at para 64.

50 Dissenting Opinion of Judge Cançado Trindade, at para 300: “...it is crystal clear that my own position, in respect of all the points which form the object of the present Judgment [...] stands in clear opposition to the view espoused by the Court's majority. 
in favour of Italy more often than Italy could have even hoped for: from recognition of an individual petition right for victims of persecution, through nullity of a compensation waiver by a State on behalf of its victims, to a right of direct access to the international judicial system. Judge Trindade identified twenty six reasons altogether to justify that the Italian rulings were not contrary to international law.

\section{Conclusions}

The Court limited its focus to the existence of sovereign immunity in civil proceedings in respect of unlawful acts committed by members of its armed forces during armed conflict. Accordingly, while the number of claims filed in the Italian courts is substantial, revealing the practical importance of the ICJ's judgment, its impact on the international law of immunities from ius cogens violations will be limited. Furthermore, the judicial panel stressed that their ruling provides a snapshot of international norms in force, without excluding the future evolution thereof, which further marginalises the importance of the judgment ${ }^{51}$.

The fact that Judges rule on the basis of, and within the limits of, existing law is not sufficient to justify the conclusion that their judgments exist within a social void ${ }^{52}$. Prior to the ICJ's judgment, the Ferrini and Voiotia precedents already led to the filing of a subsequent 250 claims in domestic courts. In the case of Ferrini, damages adjudicated by the

My dissenting position is grounded not only on the assessment of the arguments produced before the Court [...] but above all on issues of principle and on fundamental values, to which I attach even greater importance".

51 See for instance. Separate Opinion of Judge Koroma, at para 7: "Given that the Court's task is to apply the existing law, nothing in the Court's Judgment today prevents the continued evolution of the law on State immunity. In the past century, the law on State immunity has evolved considerably in a manner that has significantly circumscribed the circumstances in which a State is entitled to immunity. It is possible that further exceptions to State immunity will continue to develop in the future. The Court's Judgment applies the law as it exists today".

52 Which is evidenced for instance by judge Bennouna's referral to Rosalyn Higgins' remarks concerning balance between law and justice, and to Vaughan Lowe's work on political function of law, or judge Keith's comments on international politics. 
Corte d'Appello di Firenze amounted to Euro $109^{\prime} 000^{53}$. It is fair to assume that some part of the 120,000 uncompensated victims refrained from failing their claim until the first precedent was set. Accordingly, in Italy alone, where the number of forced workers was relatively low, the ICJ's ruling could have launched an avalanche of claims. The perspective of astronomical compensation to be paid by Germany, the back bone of the Eurozone especially during the current financial crisis, is frightening both in terms of the direct fiscal burden it would impose and the conceivable economic implications for the global economy. Still more worrying would be the possibility of a German retrospective claim, based on the GermanItalian agreements of 2.6.1961, against Italy, which has been on the brink of a sovereign default for several months.

Although it appeared, following the Al-Adsani judgment, as if the international community was ready for yet another breakthrough in the development of HRs law, even prior to the initiation of ICJ proceedings in Ferrini, the Italian administration consistently supported the German position. In this light, the stay of enforcement measures against Villa Vigoni and the bilateral declaration supporting referral of the situation to the ICJ creates a somewhat different impression. The Court, faced with an important axiological conflict between individual rights and an older principle of state sovereignty (in its classical form), listened to the arguments of both parties, one of which was effectively playing the role of advocatus diaboli. Had the Italian arguments been supported by an equally strong political and ethical conviction, perhaps the Court would have more easily established a precedent with far-reaching consequences.

Finally it should be noted that, while Germany has unequivocally condemned the facts of WWII, Italy has never properly examined its historical conscience. The equal treatment of forced workers, regardless of which side they fought during the war, represented a political compromise, ${ }^{54}$ revision of which would reopen painful wounds.

Given this situation, even if a contrary ruling was thinkable, it is not evident that the benefits of individual pecuniary compensation (which would be symbolic given the intangible character of the harm)

53 Euro 30'000 of compensation and 4\% annual interest rate since 1945, G. Masiero, Internato in un lager tedesco: la Germania deve risarcirlo, http://bit.ly/zQp2xJ; La Nazione, Risarcimenti per le stragi naziste: avvocato tedesco contro al Germania (21.02.2012).

54 Rai Storia, Prigionieri - L'ultimo inverno, 21.02.2012. 
should prevail over the attendant social, political and economic costs. Accordingly, one may remain sceptical about references to the principles of justice made by several judges, which were generally given without due consideration of a broader context.

As regards the ICJ's reasoning, it is surprising how narrowly the Court defined the problem in question. It seems that the axiological dilemma underpinning the case required at least a systematic approach: analysis of relations between fundamental, imperative HRs (which cannot be waived even by their beneficiaries) and dispositive, procedural provisions. Consistent repetition in the judgment merely to the claim of immunity, as opposed to the legality of the alleged conduct, did not resolve the underlying problem.

From the standpoint of the function of sovereign immunities fostering friendly relations between nations - judicial impunity towards the perpetrators of international crimes poses a far greater threat to the international community, than the threat of discretionary jurisdictional privilege. The protection of universal values should preoccupy the Court to an even greater extent than adjudication on Ferrini's claim lies in the Italian interest. Anyhow, as noted by judge Gaja, the prevalence of an aggressor's sovereignty over the sovereignty of the State occupied by foreign armed forces is illogical and most difficult to justify. Having said that, the inclusion of international order considerations opens the field to historical revisionism; doing so without taking account of the broader context mentioned above, would lead to a dishonest argument.

It is also worth recalling that the German Federal Constitutional Court ruled that:

"the fundamental rights safeguarded by the Basic Law take their place in a constitutional framework as a body of rules representing a unified purpose and are accordingly to be interpreted and applied in harmony and coordination with other legal interests conferred or recognized thereby. [...] The substantive content of fundamental rights and, indeed, of human rights on the other hand is unconditional and must continue in existence despite the existence of sovereign powers [of supranational organisations such as the EEC]" 55 .

55 Solange II-decision, 2 BvR 197/83, BVerfGE 73, 339. English translation available of http://bit.ly/GIcPpl (12.05.2012). 
Accordingly, the Court stated that it would not apply supranational regulation unless this external legal order ensured effective protection of the essential content of fundamental rights. Accordingly, the protection of friendly relations with Italy and the adequate allocation of jurisdiction cannot threaten the core of fundamental rights.

It is surprising that two judges in the same case could have simultaneously declared that the victims of persecution failed to utilise all available possibilities to asserting their rights (Bennouna) and that they had no alternative (Yusuf). This indicates the extent to which the ICJ failed to clarify the relationship between sovereign immunity and international law on responsibility.

Although, for the purposes of the tort exception, the cited conventions and domestic codifications do not rely on the distinction between acts de iure imperii and de iure gestionis, the ICJ concluded that international law at this point is unclear.

Nevertheless, even if the absence of a common opinio iuris justifies the choice of one solution over the alternative, the Court should have taken account of the fact that Germany is a party to the European Convention, especially since it referred to reservations made upon ratification by two other contracting States that were not parties to the dispute in question. It therefore seems more precise to perceive sovereign immunity as a privilege that can be waived and not an inalienable right.

Indicating a perceived incoherence in domestic rulings, the ICJ stressed that it is not scrutinizing abstract customary exceptions to sovereign immunity but, rather, particular military operations undertaken in Italy during WWII. First, this should not have been the case given the reasons underpinning the rejection of Italy's counterclaim. Second, in respect of intertemporal problems, the ICJ attached huge importance to the procedural nature of State immunity. This should, however, have resulted in at least a favourable approach towards the line of rulings in the State of proceeding, instead of the quantitative comparison offered by the ICJ.

The Court also stressed the importance of distinguishing between immunities in civil and criminal matters. While this may be justified in terms of State officials, it appears to this writer unjustified and incoherent to apply the same logic to the civil and criminal responsibility of a State. 
Even though the Court rejected the analogy of denying immunity to State officials responsible for international crimes, Italy was still obliged under international law not to recognise unlawful acts.

Furthermore, while the distinction between procedural and substantive norms (and first and second degree norms) is unquestionable in a hierarchical legal system, even one as shallow as international law, fundamental norms must be granted priority. Such norms include ius cogens norms penalising unpardonable war crimes, crimes against humanity and aggression. Such core principles are necessary for the subsistence of the international community. The ICJ was satisfied with the statement that the tort exception was inapplicable to the conduct of armed forces; however neither the Italian courts nor administration doubted this. Ferrini's claim and application to the ICJ was not based on the armed operations per se, but resulted from a war crime committed on a civilian. Such an act cannot fall within the scope of sovereign powers, which is the indirect consequence of the ICJ's ruling. The ICJ's incidental references to precedents granting priority to peremptory norms over sovereign immunity, without due explanation, creates the impression of an unfinished reasoning.

It is only partially possible to adhere to the conclusion concerning the alleged logical inconsistency of claiming that a procedural defence should depend upon the gravity of the substantive act. Taking a closer look at various exceptions to immunity one observes that, although the tort exception could be applied by objective criteria, the commercial act exception to immunity actually requires a careful analysis of the substance of the claim (which in Ferrini case was unnecessary anyway).

The mere moral satisfaction based on Germany's acknowledgement of guilt was evidently insufficient for Mr. Ferrini, who sought damages in addition. At the same time the examination proceeding in Italy could, at most, have concluded with the granting of an execution title. However, the ICJ decided that the procedural obstacles meant that the claim should not have been recognised. During proceeding before the ICJ, however, Germany and several judges' opinions admitted that Germany's responsibility for war crimes and crimes against humanity was beyond any doubt. Indirectly, this means that there was no true litis between the parties. This does not alter the fact that the broader scope of immunity from execution makes it unlikely for a plaintiff to judicially enforce the 
judgment. In this sense, the ICJ's decision realised all goals that could reasonably have been expected in a domestic court. This, however, brings us back to the beginning, which is to ask why the claim was filed in the first place. 